\title{
Formation of Intermetallic Compounds in the Ni Bearing Lead Free Composite Solders
}

\author{
Joo Won Lee, Zin Hyoung Lee*1 and Hyuck Mo Lee*2 \\ Department of Materials Science and Engineering Korea Advanced Institute of Science and Technology, \\ Kusung-dong 373-1, Yusung-gu, Taejon, Korea 305-701
}

\begin{abstract}
Quaternary $\mathrm{Sn}-\mathrm{Ag}-\mathrm{Cu}-\mathrm{Ni}$ composite solders were made with several different ratios of $\mathrm{Cu} / \mathrm{Ni}$ to study the effect of $\mathrm{Cu} / \mathrm{Ni}$ on the type of intermetallic compound phase at the joint interface. The eutectic solders of $\mathrm{Sn}-3.5 \mathrm{Ag}$ and $\mathrm{Sn}-3.5 \mathrm{Ag}-0.7 \mathrm{C}$ (numbers are all in mass\% unless specified otherwise) were used as references together with the ternary composite solder of Sn-3.0Ag-7.0Cu tested previously. When the ratio of excess $\mathrm{Cu} / \mathrm{Ni}$ alloyed in the original composite solder was $7: 3,6: 4$ and 5:5, the reinforcing intermetallic compound (IMC) was (Cu,Ni) $)_{6} \mathrm{Sn}_{5}$. When the ratio was $\mathrm{Cu}: \mathrm{Ni}=3: 7$, both phases of $(\mathrm{Cu}, \mathrm{Ni})_{6} \mathrm{Sn}_{5}$ and $(\mathrm{Ni}, \mathrm{Cu})_{3} \mathrm{Sn}_{4}$ showed up while only the $(\mathrm{Ni}, \mathrm{Cu})_{3} \mathrm{Sn}_{4}$ phase was observed in the solder with a $\mathrm{Cu}: \mathrm{Ni}$ ratio of $1: 9$. For the interfacial reaction of the eutectic $\mathrm{Sn}-3.5 \mathrm{Ag}-0.7 \mathrm{Cu}$ with the rolled $\mathrm{Ni}$ substrate, the thick $(\mathrm{Cu}, \mathrm{Ni})_{6} \mathrm{Sn}_{5}$ layer was formed on the thin $(\mathrm{Ni}, \mathrm{Cu})_{3} \mathrm{Sn}_{4}$ layer. The addition of $\mathrm{Ni}$ was effective to suppress the formation of the thick $(\mathrm{Cu}, \mathrm{Ni})_{6} \mathrm{Sn}_{5}$ IMC. When the $\left(\mathrm{Cu}_{x} \mathrm{Ni}_{1-x}\right)_{6} \mathrm{Sn}_{5}$ IMC layer was formed, the value of $x$ was lager than 0.6 while for the case of $\left(\mathrm{N}_{y} \mathrm{Cu}_{1-y}\right)_{3} \mathrm{Sn}_{4}$ the value of $y$ was larger than 0.8 . The addition of Ni enhanced the bonding properties and retarded the growth of IMC. In the Ni bearing composite solder, there was no significant sedimentation of reinforcing particles during reflow, which took place commonly in the other composite solders. Wettability and mechanical properties of the Ni bearing solders were also compared.
\end{abstract}

(Received May 26, 2005; Accepted August 5, 2005; Published November 15, 2005)

Keywords: composite solder, nickel bearing solder, solder interface, intermetallics, $\mathrm{Cu}_{6} \mathrm{Sn}_{5}, \mathrm{Ni}_{3} \mathrm{Sn}_{4}$

\section{Introduction}

Electronic devices such as computers and cellular phones have become thinner and smaller with more complicated functions. Miniaturization of these electronic devices demands better reliability of the solder joint, because a small solder bump experiences harsh conditions caused by increased heat emission per unit size. One approach to improve reliability is using a composite solder, which consists of a solder matrix and reinforcements. Composite solders are known to have good reliability because the reinforcing particles can suppress grain-boundary sliding, IMC formation, grain growth, and furthermore, uniformly redistribute stress. ${ }^{1-14)}$

According to the conventional manufacturing processes of composite solders, ${ }^{1-5)}$ solder pastes or solder powders are intentionally mixed with $\mathrm{Cu}_{6} \mathrm{Sn}_{5}$ reinforcements. In other methods, ${ }^{6-12)}$ the solder is mixed with metal powders, such as $\mathrm{Ag}, \mathrm{Cu}$ and $\mathrm{Ni}$, and reflowed to form IMC particles inside the solder matrix. However, the latter methods enable only the surface area of metal powders to react with mostly $\mathrm{Sn}$ of the $\mathrm{Sn}$-rich solder to form intermetallic particles while the former methods are not practiced these days.

The authors devised innovative methods for fabricating composite solders, which consisted of the $\mathrm{Sn}-\mathrm{Ag}$ solder matrix and the $\mathrm{Cu}_{6} \mathrm{Sn}_{5}$ particles. ${ }^{13,14)}$ Composite solders were prepared by a novel in-situ process, solidification and deformation. The molten solder with the same composition of the resultant composite is rapidly solidified as thin sheet. During solidification, primary IMC dendrites form in the solder matrix and they are crushed into fine particles and redistributed by way of plastic working. IMC reinforcements made by this method were much finer than those by the

\footnotetext{
*1 deceased, June, 2004

${ }^{* 2}$ Corresponding author, E-mail: hmlee@kaist.ac.kr
}

conventional manufacturing method. Thus, it was motivated to expand the method to incorporate $\mathrm{Ni}$ containing IMCs as well as $\mathrm{Cu}$ bearing IMCs.

In this work, $\mathrm{Sn}-\mathrm{Ag}$ based solders reinforced with $(\mathrm{Cu}, \mathrm{Ni})_{6} \mathrm{Sn}_{5}$ and $(\mathrm{Ni}, \mathrm{Cu})_{3} \mathrm{Sn}_{4}$ particles were manufactured. These solders and their joints with $\mathrm{Cu}$ and $\mathrm{Ni}$ were studied. The interfacial phase and microstructure, the joint strength after soldering and aging were investigated with an emphasis on the effect of variation in the ratio of $\mathrm{Cu} / \mathrm{Ni}$.

\section{Experimental Procedures}

Composite solders were rapidly solidified. Primary IMC dendrites formed in the solder matrix during solidification were crushed into fine particles and redistributed by way of rolling or drawing. The details of fabrication are available in earlier publications. ${ }^{13,14)}$ The discs punched out of the rolled strip are remelted in hot oil to be spheroidized, thereby becoming solder balls with an average diameter of $630 \mu \mathrm{m}$.

Quaternary $\mathrm{Sn}-\mathrm{Ag}-\mathrm{Cu}-\mathrm{Ni}$ composite solders were made with several different ratios of $\mathrm{Cu} / \mathrm{Ni}$. The ratios of $\mathrm{Cu} / \mathrm{Ni}$ (in mass \%) in excess of the quaternary eutectic composition to be determined later in this study are as follows: $0.11,0.43$, 1.0, 1.5 and $2.33(\mathrm{Cu}: \mathrm{Ni}=1: 9,3: 7,5: 5,6: 4$ and $7: 3)$ and additional $\mathrm{Cu}$ and $\mathrm{Ni}$ elements above the eutectic composition were assumed to form $\mathrm{Cu}_{6} \mathrm{Sn}_{5}$ or $\mathrm{Ni}_{3} \mathrm{Sn}_{4}$ respectively, and the total volume of IMC was aimed at 15 volume\%. Their compositions are shown in Table 1. The binary eutectic non-composite solder of $\mathrm{Sn}-3.5 \mathrm{Ag}$ (solder A) and the ternary near-eutectic non-composite solder of $\mathrm{Sn}-3.5 \mathrm{Ag}-0.7 \mathrm{Cu}$ (solder B), were used as references together with the previous ternary composite solder of $\mathrm{Sn}-3.0 \mathrm{Ag}-7.0 \mathrm{Cu}$ (solder C). ${ }^{13,14)}$

For the substrates, $\mathrm{Cu}$ and $\mathrm{Ni}$ were used in the form of a printed circuit board (PCB) and a rolled plate. Metal plates 
Table 1 Composition and types of solders.

\begin{tabular}{|c|c|c|c|}
\hline Solders & Composition (in wt\%) & Ration of $\mathrm{Cu} / \mathrm{Ni}^{*}(\mathrm{Cu}: \mathrm{Ni})$ & Remarks \\
\hline A & $\mathrm{Sn}-3.5 \mathrm{Ag}$ & & $\mathrm{Sn}-\mathrm{Ag}$ eutectic \\
\hline $\mathrm{B}$ & $\mathrm{Sn}-3.5 \mathrm{Ag}-0.7 \mathrm{Cu}$ & & $\mathrm{Sn}-\mathrm{Ag}-\mathrm{Cu}$ eutectic \\
\hline $\mathrm{D}$ & $\mathrm{Sn}-3.2 \mathrm{Ag}-0.6 \mathrm{Cu}-0.7 \mathrm{Ni}$ & & $\mathrm{Sn}-\mathrm{Ag}-\mathrm{Cu}-\mathrm{Ni}$ eutectic \\
\hline $\mathrm{E}$ & $\mathrm{Sn}-2.7 \mathrm{Ag}-1.1 \mathrm{Cu}-4.8 \mathrm{Ni}$ & $0.11(1: 9)$ & $\mathrm{Sn}-\mathrm{Ag}-\mathrm{Cu}-\mathrm{Ni}$ composite \\
\hline $\mathrm{F}$ & $\mathrm{Sn}-2.7 \mathrm{Ag}-2.2 \mathrm{Cu}-4.1 \mathrm{Ni}$ & $0.43(3: 7)$ & $\mathrm{Sn}-\mathrm{Ag}-\mathrm{Cu}-\mathrm{Ni}$ composite \\
\hline $\mathrm{G}$ & $\mathrm{Sn}-2.7 \mathrm{Ag}-3.8 \mathrm{Cu}-3.6 \mathrm{Ni}$ & $1.0 \quad(5: 5)$ & $\mathrm{Sn}-\mathrm{Ag}-\mathrm{Cu}-\mathrm{Ni}$ composite \\
\hline $\mathrm{H}$ & $\mathrm{Sn}-2.8 \mathrm{Ag}-4.8 \mathrm{Cu}-2.9 \mathrm{Ni}$ & $1.5(6: 4)$ & $\mathrm{Sn}-\mathrm{Ag}-\mathrm{Cu}-\mathrm{Ni}$ composite \\
\hline $\mathrm{I}$ & $\mathrm{Sn}-2.8 \mathrm{Ag}-5.1 \mathrm{Cu}-2.5 \mathrm{Ni}$ & $2.33(7: 3)$ & $\mathrm{Sn}-\mathrm{Ag}-\mathrm{Cu}-\mathrm{Ni}$ composite \\
\hline
\end{tabular}

$\left(\mathrm{Cu} / \mathrm{Ni}^{*}\right.$ : projected $\mathrm{Cu} / \mathrm{Ni}$ ratio in excess of the quaternary eutectic composition)

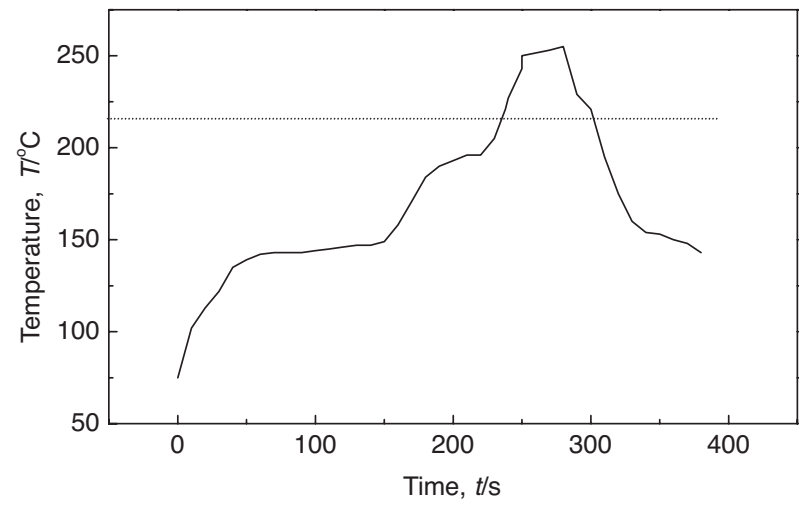

Fig. 1 Reflow temperature profile.

were mechanically polished before reflow. Rosin mildly activated (RMA) flux was painted on the substrate and it was reflowed according to the temperature profile shown in Fig. 1. The solder joints were then isothermally aged at $120^{\circ} \mathrm{C}$ for up to $36 \mathrm{~d}$.

To study the interfacial microstructure, each solder joint was vertically cut and cold mounted. They were then polished through a $1 \mu \mathrm{m}$ diamond. The interface was examined using back scattered scanning electron microscopy (SEM) operated at $25 \mathrm{kV}$ and the compositions of the interfacial IMC were measured by energy dispersive X-ray spectroscopy (EDX: EDAX DX-4eDX PhiZAF System version 2.11) operated at $20 \mathrm{kV}$. The spatial resolution was approximately a $1 \mu \mathrm{m}$ diameter area around the target point and the compositions were determined by an average of ten point measurements. The phases formed at the interface and inside the composite were identified by the X-ray diffraction (XRD) analysis and the layer thickness of IMCs was obtained as the averaged value by area of SEM micrographs.

The differential scanning calorimetry (DSC) analysis was employed to measure the eutectic temperature of the quaternary $\mathrm{Sn}-\mathrm{Ag}-\mathrm{Cu}-\mathrm{Ni}$ solder. It was put into aluminum pan and the thermal scan was carried out at the heating rate of $1^{\circ} \mathrm{C} / \mathrm{min}$ from 40 to $280^{\circ} \mathrm{C}$ under nitrogen. The solder joint strength was measured using a Dage 2400 ball shear tester. The jig speed was $100 \mu \mathrm{m} / \mathrm{s}$ and the jig height was $10 \mu \mathrm{m}$ from the bottom while the load applied was $50 \mathrm{~g}$. Wetting angles were measured using solder foils $(10 \mathrm{~mm}$ diameter $)$ reflowed on the rolled $\mathrm{Cu}$ substrate.
Table 2 List of sources of thermodynamic parameters.

\begin{tabular}{ccccc}
\hline Binary system & Ref. & & Binary System & Ref. \\
\cline { 1 - 1 } $\mathrm{Ag}-\mathrm{Cu}$ & $16)$ & & $\mathrm{Cu}-\mathrm{Ni}$ & $19)$ \\
$\mathrm{Ag}-\mathrm{Ni}$ & $17)$ & & $\mathrm{Cu}-\mathrm{Sn}$ & $20)$ \\
$\mathrm{Ag}-\mathrm{Sn}$ & $18)$ & & $\mathrm{Ni}-\mathrm{Sn}$ & $21)$ \\
\hline
\end{tabular}

All the ternary and quaternary systems are extrapolated from the binary thermodynamic descriptions.

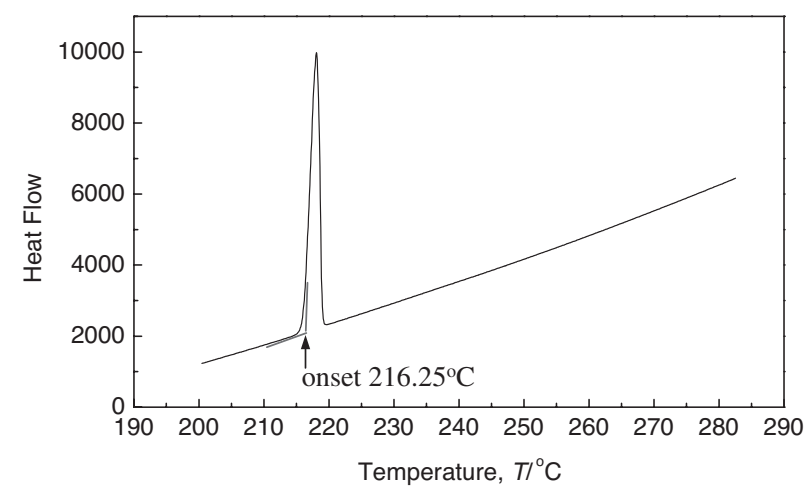

Fig. 2 Heat flow versus temperature curve for the $\mathrm{Sn}-\mathrm{Ag}-\mathrm{Cu}-\mathrm{Ni}$ eutectic solder, D.

\section{Results and Discussion}

To determine the exact eutectic composition of the quaternary $\mathrm{Sn}-\mathrm{Ag}-\mathrm{Cu}-\mathrm{Ni}$ solder, the phase equilibria calculations were made using a Thermo-Calc program. ${ }^{15)}$ Table 2 lists up the references of the thermodynamic description and parameters of the binary systems used in this study. ${ }^{16-21)}$ All the ternary and quaternary systems were extrapolated from binary thermodynamic descriptions only. The quaternary eutectic reaction was calculated to occur at $\mathrm{Sn}-3.24 \mathrm{Ag}-$ $0.64 \mathrm{Cu}-0.75 \mathrm{Ni}$ and $216^{\circ} \mathrm{C}$. To confirm the calculations, the DSC analysis of the solder specimen with the same composition (solder D) was performed. The curve of heat flow versus temperature is shown in Fig. 2, which shows only one sharp peak corresponding to the invariant reaction. No other phase change was observed. The onset temperature was $216.25^{\circ} \mathrm{C}$, almost the same as the calculated one. Thereby, in this work, $\mathrm{Sn}-3.24 \mathrm{Ag}-0.64 \mathrm{Cu}-0.75 \mathrm{Ni}$ was taken as the quaternary eutectic composition.

Even if the calculated temperature is very close to the onset 


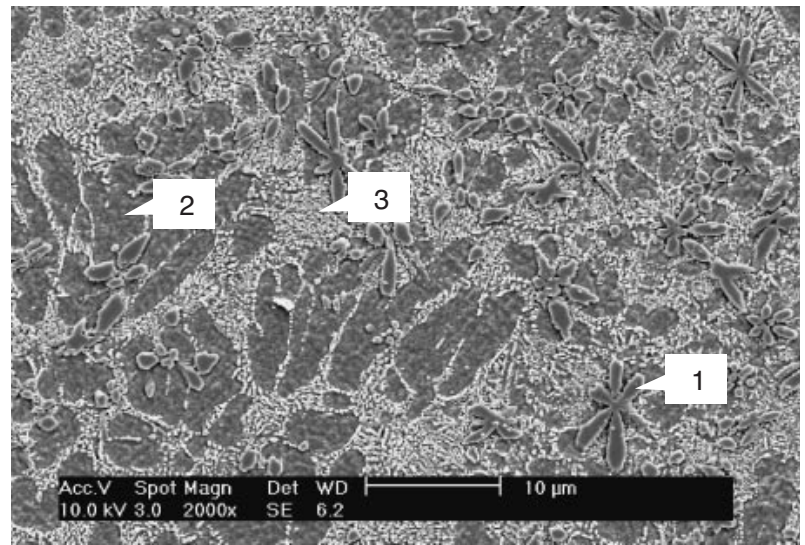

Fig. 3 Microstructure of the $(\mathrm{Cu}, \mathrm{Ni})_{6} \mathrm{Sn}_{5}$ IMC reinforced $\mathrm{Sn}-\mathrm{Ag}-\mathrm{Cu}-\mathrm{Ni}$ composite solder, I.

Table 3 Reinforcing IMC types and composition according to $\mathrm{Cu} / \mathrm{Ni}$ ratio above eutectic composition.

\begin{tabular}{ccl}
\hline $\begin{array}{c}\text { Composite } \\
\text { Solders }\end{array}$ & $\begin{array}{c}\text { Ratio of } \mathrm{Cu}: \mathrm{Ni} \\
\text { alloyed (aimed) }\end{array}$ & \multicolumn{1}{c}{ Type of IMC and Composition } \\
\hline $\mathrm{E}$ & $1: 9$ & $\approx\left(\mathrm{Ni}_{0.91}, \mathrm{Cu}_{0.09}\right)_{3} \mathrm{Sn}_{4}$ \\
$\mathrm{~F}$ & $3: 7$ & $\approx\left(\mathrm{Ni}_{0.80}, \mathrm{Cu}_{0.20}\right)_{3} \mathrm{Sn}_{4}+\left(\mathrm{Cu}_{0.55}, \mathrm{Ni}_{0.45}\right)_{6} \mathrm{Sn}_{5}$ \\
$\mathrm{G}$ & $5: 5$ & $\approx\left(\mathrm{Cu}_{0.53}, \mathrm{Ni}_{0.47}\right)_{6} \mathrm{Sn}_{5}$ \\
$\mathrm{H}$ & $6: 4$ & $\approx\left(\mathrm{Cu}_{0.61}, \mathrm{Ni}_{0.39}\right)_{6} \mathrm{Sn}_{5}$ \\
$\mathrm{I}$ & $7: 3$ & $\approx\left(\mathrm{Cu}_{0.72}, \mathrm{Ni}_{0.28}\right)_{6} \mathrm{Sn}_{5}$ \\
\hline
\end{tabular}

temperature of the DSC analysis it is notable that there are some uncertainties in the eutectic composition, because the undercooling is significant for the Sn-based alloy and the DSC result is not that sensitive to discern two very close reactions. Furthermore, the thermodynamic calculations have been made using binary systems only. No ternary or quaternary descriptions were included.

Figure 3 shows the SEM micrograph of the as-cast solder I $(\mathrm{Cu}: \mathrm{Ni}=7: 3)$. The area marked by number 1 shows the $(\mathrm{Cu}, \mathrm{Ni})_{6} \mathrm{Sn}_{5}$ reinforcing dendrites. The region 2 with dark contrast is composed of primary $\mathrm{Sn}$ dendrites and the region 3 refers to the eutectic-type structure of $\mathrm{Sn}, \mathrm{Ag}_{3} \mathrm{Sn}$ and $(\mathrm{Cu}, \mathrm{Ni})_{6} \mathrm{Sn}_{5}$ phases. To investigate which kind of reinforcing intermetallic phases are formed in the matrix, the XRD analysis were conducted along with EDX analysis. When the ratio of excess $\mathrm{Cu} / \mathrm{Ni}$ alloyed in the original composite solder was $7: 3,6: 4$ and $5: 5$, the reinforcing IMC phase was $(\mathrm{Cu}, \mathrm{Ni})_{6} \mathrm{Sn}_{5}$. The compositions of IMC particles are shown in Table 3. When the ratio was $\mathrm{Cu}: \mathrm{Ni}=$ $3: 7$, both phases of $(\mathrm{Cu}, \mathrm{Ni})_{6} \mathrm{Sn}_{5}$ and $(\mathrm{Ni}, \mathrm{Cu})_{3} \mathrm{Sn}_{4}$ showed up while only the $(\mathrm{Ni}, \mathrm{Cu})_{3} \mathrm{Sn}_{4}$ phase was observed in the solder $\mathrm{E}(\mathrm{Cu}: \mathrm{Ni}=1: 9)$.

The phase formation in the as-solidified $\mathrm{Sn}-\mathrm{Ag}-\mathrm{Cu}-\mathrm{Ni}$ quaternary alloys has been also reported by the Chen group. ${ }^{22,23)}$ The formation of $(\mathrm{Cu}, \mathrm{Ni})_{6} \mathrm{Sn}_{5}$ and $(\mathrm{Ni}, \mathrm{Cu})_{3} \mathrm{Sn}_{4}$ is mostly affected by the ratio of $\mathrm{Cu} / \mathrm{Ni}$ but not much by the added amount of Ag.

The microstructure of the $(\mathrm{Ni}, \mathrm{Cu})_{3} \mathrm{Sn}_{4}$ reinforced composite solder $\mathrm{E}(\mathrm{Cu}: \mathrm{Ni}=1: 9)$ is shown in Fig. 4. The particles with dark contrast are $(\mathrm{Ni}, \mathrm{Cu})_{3} \mathrm{Sn}_{4}$ IMCs. The solubility limit of $\mathrm{Ni}$ in $(\mathrm{Cu}, \mathrm{Ni})_{6} \mathrm{Sn}_{5}$ is around $0.45-0.5$ based

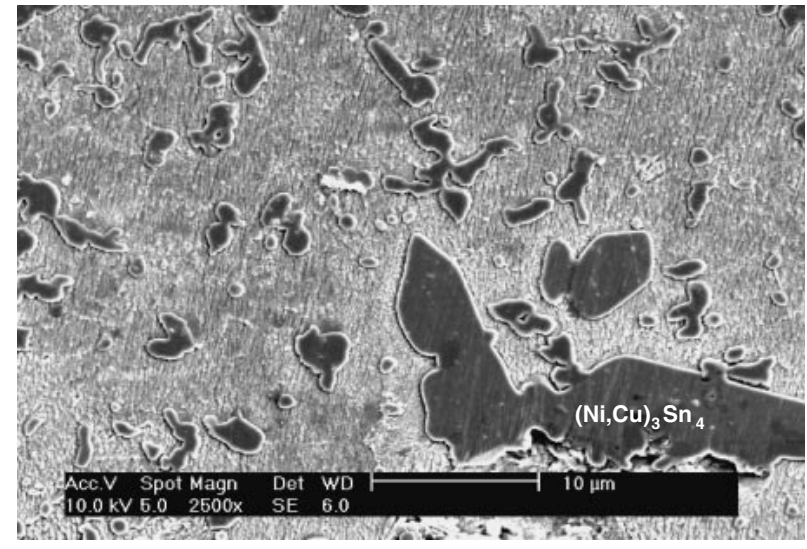

Fig. 4 Microstructure of $(\mathrm{Ni}, \mathrm{Cu})_{3} \mathrm{Sn}_{4}$ IMC reinforced $\mathrm{Sn}-\mathrm{Ag}-\mathrm{Cu}-\mathrm{Ni}$ composite solder, E.

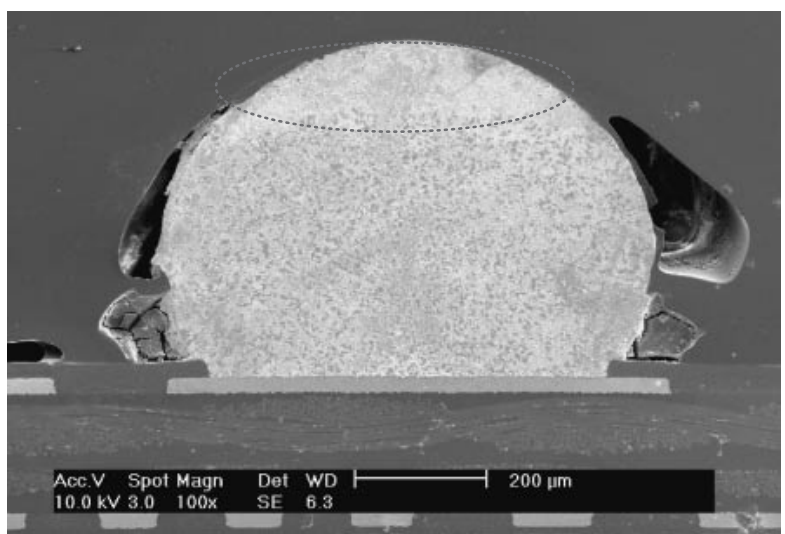

(a)

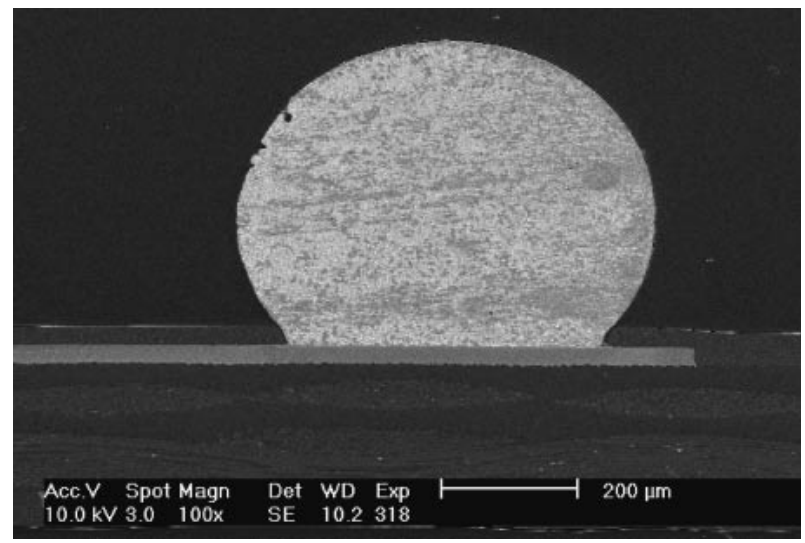

(b)

Fig. 5 Cross-sectional micrographs of (a) $\mathrm{Sn}-\mathrm{Ag}-\mathrm{Cu}$ composite solder, C and (b) $\mathrm{Sn}-\mathrm{Ag}-\mathrm{Cu}-\mathrm{Ni}$ composite solder, $\mathrm{H}$. Particle-free zone is observed at the upper part of solder $\mathrm{C}$ (a) while it is absent in solder $\mathrm{H}$ (b).

on Table 3. Even though the $(\mathrm{Ni}, \mathrm{Cu})_{3} \mathrm{Sn}_{4}$ primary dendrites were not detected in the solder $\mathrm{G}(\mathrm{Cu}: \mathrm{Ni}=5: 5)$, there is a possibility for $(\mathrm{Ni}, \mathrm{Cu})_{3} \mathrm{Sn}_{4}$ to form, because the composition of the solder $\mathrm{G}$ is located almost at the end of solubility limit of Ni. Therefore in this study, the solder $\mathrm{H}(\mathrm{Cu}: \mathrm{Ni}=6: 4)$ that has the highest $\mathrm{Ni}$ content without forming $(\mathrm{Ni}, \mathrm{Cu})_{3} \mathrm{Sn}_{4}$ was selected as an exemplary $(\mathrm{Cu}, \mathrm{Ni})_{6} \mathrm{Sn}_{5}$ reinforced $\mathrm{Sn}-$ $\mathrm{Ag}-\mathrm{Cu}-\mathrm{Ni}$ composite. 
In the ternary composite solder $\mathrm{C}$, particle sedimentation was observed as seen in Fig. 5. At the upper part of the composite solder ball, the particle-free zone was found while this behavior was not observed in the composite solder $\mathrm{H}$ $(\mathrm{Cu}: \mathrm{Ni}=6: 4)$. In the solder $\mathrm{H}$, the IMC phase was (Cu,Ni) ${ }_{6} \mathrm{Sn}_{5}$ while it was $\mathrm{Cu}_{6} \mathrm{Sn}_{5}$ in the case of solder $\mathrm{C}$ (no Ni containing). The particle-free zone seems to result from gravitational sedimentation. The densities of the eutectic $\mathrm{Sn}-\mathrm{Ag}-\mathrm{Cu}$ solder and the $\mathrm{Cu}_{6} \mathrm{Sn}_{5}$ phase are 7500 and $8200 \mathrm{~kg} / \mathrm{m}^{3}$, respectively. ${ }^{24,25)}$ Because $\mathrm{Cu}_{6} \mathrm{Sn}_{5}$ is heavier than the solder matrix, it tends to sink down to the substrate during reflow. But there was no significant sedimentation in the $\mathrm{Sn}-\mathrm{Ag}-\mathrm{Cu}-\mathrm{Ni}$ composite solder $\mathrm{H}$, because the $\mathrm{Ni}$ substitution makes $(\mathrm{Cu}, \mathrm{Ni})_{6} \mathrm{Sn}_{5}$ lighter in weight. The atomic weight of $\mathrm{Cu}$ and $\mathrm{Ni}$ are 63.55 and $58.70 \mathrm{~g} / \mathrm{mol}$, and their radii are 0.157 and $0.162 \mathrm{~nm}$. This difference may not be large enough to change the density of $(\mathrm{Cu}, \mathrm{Ni})_{6} \mathrm{Sn}_{5}$. An analysis by Pauling ${ }^{26)}$ may be used to assess the nature of bonding in IMC. $\mathrm{Cu}_{6} \mathrm{Sn}_{5}$ has a hexagonal NiAs $\left(B 8_{1}\right)$ type structure with $a=0.419 \mathrm{~nm}$ and $c=0.509 \mathrm{~nm}$. The interatomic distance of fractional bonding materials such as $\mathrm{Cu}_{6} \mathrm{Sn}_{5}$ is varied by the bonding number $n$ and the valence of elements. The substitution of $\mathrm{Ni}$ can change the lattice parameter and density, even though the densities of $\mathrm{Ni}$ and $\mathrm{Cu}$ are not much different. Based on this reasoning, there was no remarkable reinforcement sedimentation in the solder $\mathrm{H}$.

The ball shear strength is shown as a function of aging time in Fig. 6. Black, gray and white symbols represent $\mathrm{Sn}-\mathrm{Ag}-$ $\mathrm{Cu}-\mathrm{Ni}$ composite (solder $\mathrm{H}$ ), $\mathrm{Sn}-\mathrm{Ag}-\mathrm{Cu}$ composite (sol$\operatorname{der} \mathrm{C}$ ) and $\mathrm{Sn}-\mathrm{Ag}$ monolithic (solder A) solders, respectively, while circle and square symbols denote reflows on $\mathrm{Ni}$ and $\mathrm{Cu}$ substrates. The $\mathrm{Sn}-\mathrm{Ag}-\mathrm{Cu}-\mathrm{Ni}$ composite solder has higher shear strength than the other solders, especially, on the Ni substrate. In other words, on the Ni substrate, the shear strength decreased most slowly with aging time. As the $\mathrm{Cu}$ addition into $\mathrm{Sn}-\mathrm{Ag}$ hardens the solder matrix and enhances bonding properties on the $\mathrm{Cu}$ substrate, ${ }^{25,27,28)}$ the

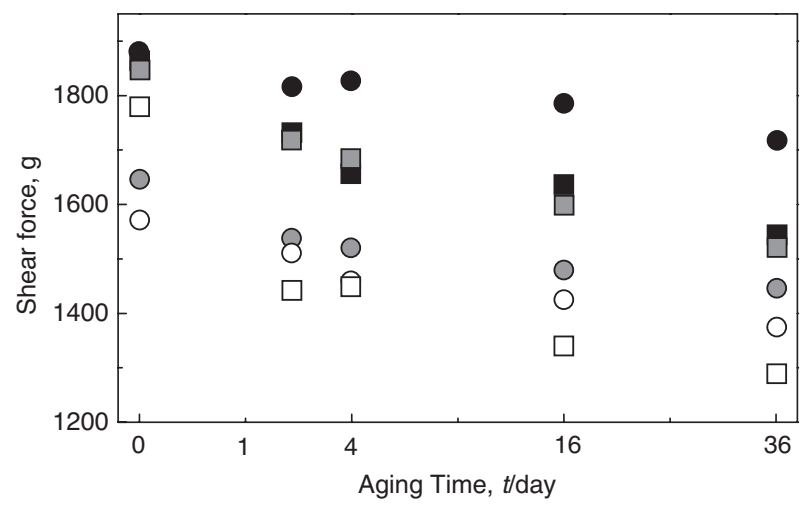

\begin{tabular}{|lll|}
\hline & Sn-Ag-Cu-Ni composite (solder $\mathrm{H}$ ) on $\mathrm{Ni}$ \\
0 & Sn-Ag-Cu-Ni composite (solder $\mathrm{H}$ ) on $\mathrm{Cu}$ \\
$\square$ & Sn-Ag-Cu & composite (solder $\mathrm{C}$ ) on $\mathrm{Ni}$ \\
$\bigcirc$ & Sn-Ag & composite (solder C) on $\mathrm{Cu}$ \\
$\square$ & Sn-Ag & monolithic (solder A) on $\mathrm{Ni}$ \\
\hline
\end{tabular}

Fig. 6 Variation of ball shear strength with aging time.

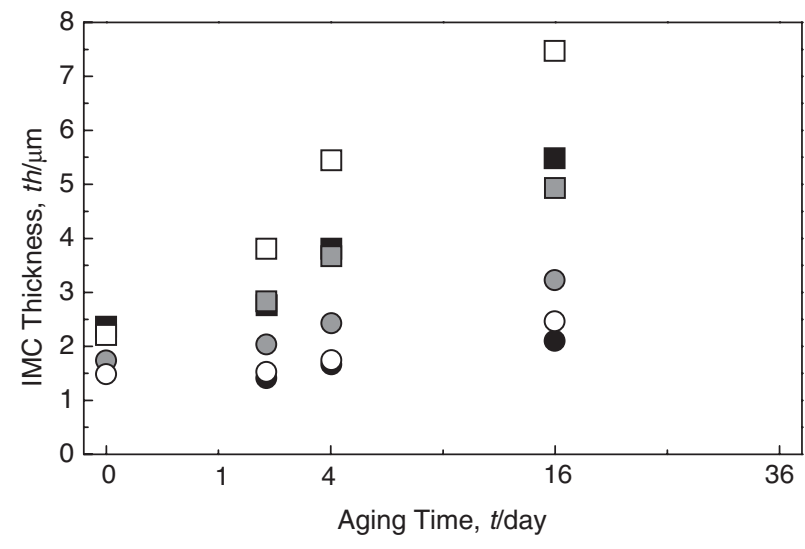

\begin{tabular}{|lll|}
\hline & Sn-Ag-Cu-Ni composite (solder $\mathrm{H}$ ) on $\mathrm{Ni}$ \\
$\mathrm{O}$ & Sn-Ag-Cu-Ni composite (solder $\mathrm{H}$ ) on $\mathrm{Cu}$ \\
$\square$ & Sn-Ag-Cu & composite (solder $\mathrm{C}$ ) on $\mathrm{Ni}$ \\
$\mathrm{O}$ & Sn-Ag-Cu & composite (solder C) on $\mathrm{Cu}$ \\
$\square$ & Sn-Ag & monolithic (solder A) on $\mathrm{Ni}$ \\
\hline
\end{tabular}

Fig. 7 Variation of IMC layer thickness with aging time.

addition of Ni into $\mathrm{Sn}-\mathrm{Ag}-\mathrm{Cu}$ is also expected to increase the bonding strength on the Ni substrate. The hardening effect may come together with the increased ductility. It is generally known that at low strain rate and displacement the composite solders are more ductile than the monolithic solders. ${ }^{1-14)}$ Then, the Ni bearing composite solders are supposed to increase reliability.

The growth of the IMC layer is plotted as a function of aging time in Fig. 7. On the $\mathrm{Cu}$ substrate, the growth of IMC was fast in the binary monolithic solder A, and the solders $\mathrm{C}$ and $\mathrm{H}$ showed similar behavior. The growth of IMC on the Ni substrate was slow compared to that on the $\mathrm{Cu}$ substrate. This behavior persisted in all the three solders of $\mathrm{A}, \mathrm{C}$ and $\mathrm{H}$, and the growth rate was more or less same. It is highly likely that the IMC was based on $\mathrm{Ni}_{3} \mathrm{Sn}_{4}$ in all the three solder joints with $\mathrm{Ni}$ and thus their growth rate and the buildup of the IMC was similar. The IMC layers are more brittle than the solder matrix and thus a thick IMC layer can be a site of mechanical weakness causing failure of the joint. Therefore, retarded growth of the IMC layer is very important to improve the solder joint reliability. It was reported that the growth of $\mathrm{Cu}_{6} \mathrm{Sn}_{5}$ in the $\mathrm{Sn}-\mathrm{Ag}-\mathrm{Cu}$ solder is slower than that of the $\mathrm{Sn}-$ $\mathrm{Ag}$ solder on the $\mathrm{Cu}$ substrate because of the reduced concentration gradient of $\mathrm{Cu}$ into the solder matrix and the decreased flux of $\mathrm{Cu}$ in turn. ${ }^{4,5,29)}$ In a similar way, it is expected that the growth of $\mathrm{Ni}_{3} \mathrm{Sn}_{4}$ can also be retarded in the $\mathrm{Ni}$ bearing composite solder on the Ni substrate.

The cross-sectional SEM micrographs of the interfacial reaction of $\mathrm{Sn}-\mathrm{Ag}-\mathrm{Cu} /$ rolled $\mathrm{Ni}$ after reflow with different $\mathrm{Cu}$ concentrations are shown in Figs. 8(a) and (b). The composition of the solder is $\mathrm{Sn}-3.5 \mathrm{Ag}-0.4 \mathrm{Cu}$ in Fig. 8(a) and $\mathrm{Sn}-3.5 \mathrm{Ag}-0.7 \mathrm{Cu}$ (solder B) in Fig. 8(b). An additional difference to be noted here is the use of a rolled Ni plate rather than $\mathrm{PCB}$ to investigate the effect of the substrate conditions. The thick $(\mathrm{Cu}, \mathrm{Ni})_{6} \mathrm{Sn}_{5}$ layer was formed on the 


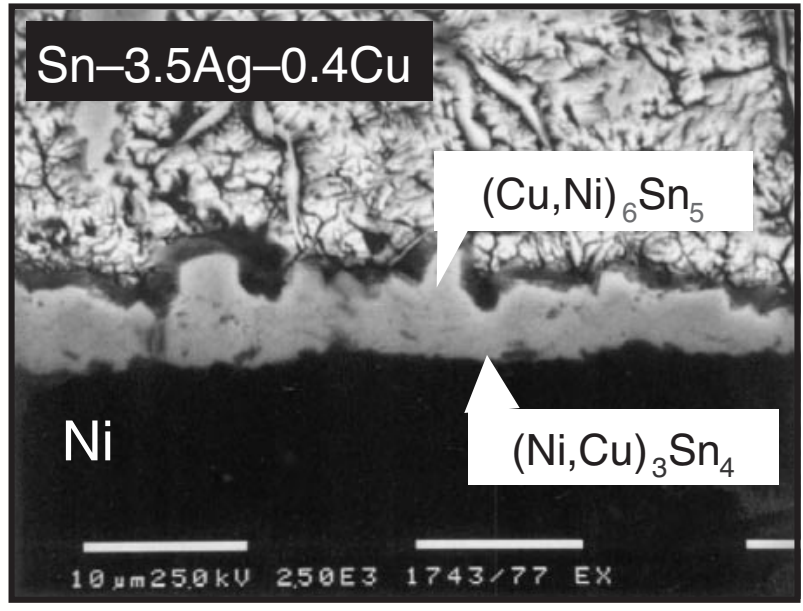

(a)

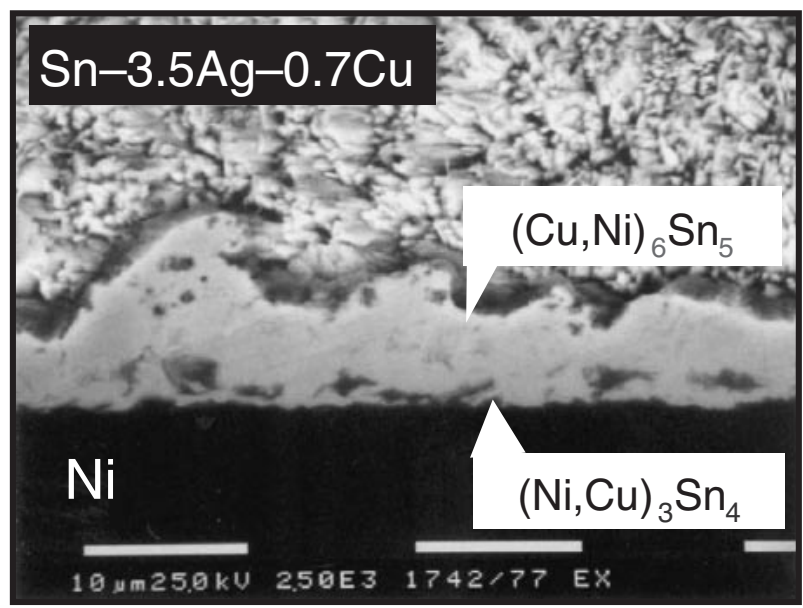

(b)

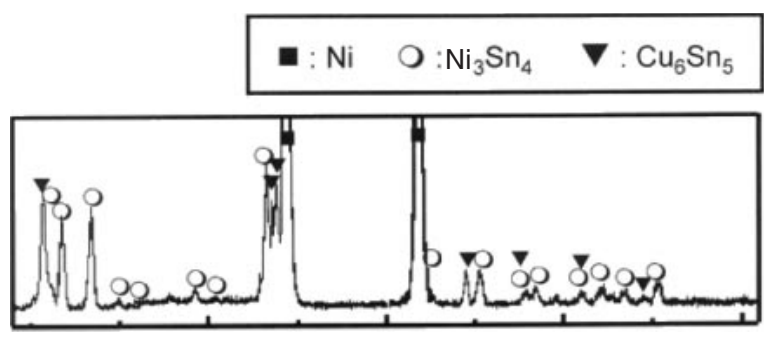

(c)

Fig. 8 Cross-sectional micrographs of the interface between the $\mathrm{Ni}$ substrate and (a) $\mathrm{Sn}-3.5 \mathrm{Ag}-0.4 \mathrm{Cu}$ (composition not listed in Table 1), (b) $\mathrm{Sn}-3.5 \mathrm{Ag}-0.7 \mathrm{Cu}$ (solder B) and (c) XRD pattern of the interfacial IMC layer in solder B as-reflowed condition.

thin $(\mathrm{Ni}, \mathrm{Cu})_{3} \mathrm{Sn}_{4}$ layer in both cases. Because $\mathrm{Cu}_{6} \mathrm{Sn}_{5}$ grows faster than $\mathrm{Ni}_{3} \mathrm{Sn}_{4}$, the formation of the thick $(\mathrm{Cu}, \mathrm{Ni})_{6} \mathrm{Sn}_{5}$ layer surely decreases the solder joint reliability. Its formation was verified by XRD in Fig. 8(c). Its peak showed up simultaneously with peaks of $(\mathrm{Ni}, \mathrm{Cu})_{3} \mathrm{Sn}_{4}$ and $\mathrm{Ni}$. When the solder B $(\mathrm{Sn}-3.5-0.7 \mathrm{Cu})$ was reflowed on the plated Ni PCB, not on the rolled $\mathrm{Ni}$ substrate, the $(\mathrm{Cu}, \mathrm{Ni})_{6} \mathrm{Sn}_{5} \mathrm{IMC}$ layer was not observed but only the $\mathrm{Ni}_{3} \mathrm{Sn}_{4}$ layer showed up. The difference seems to have originated from the different condition of the Ni substrate, whether rolled or plated, even if the reason is not clear yet. When the solder of $\mathrm{Sn}-3.5 \mathrm{Ag}-$

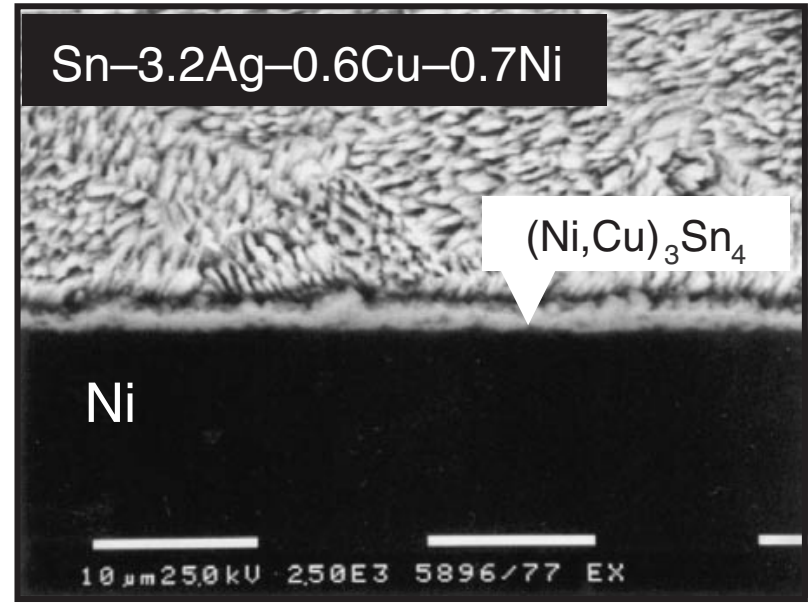

(a)

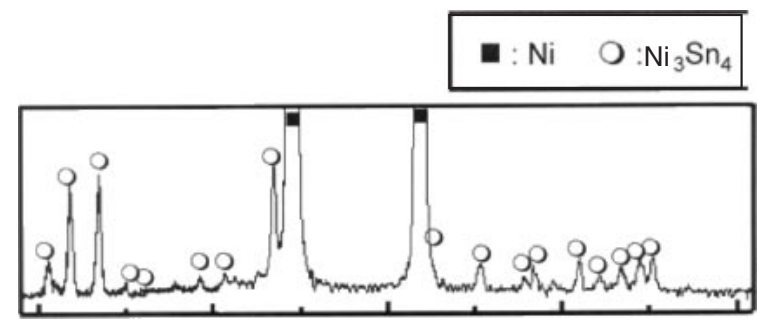

(b)

Fig. 9 (a) Cross-sectional micrograph of the interface between the $\mathrm{Ni}$ substrate and $\mathrm{Sn}-3.2 \mathrm{Ag}-0.6 \mathrm{Cu}-0.7 \mathrm{Ni}$ (solder D) and (b) XRD pattern of the IMC layer as-reflowed condition.

0.4Cu [tested in Fig. 8(a)] was reflowed with the plated $\mathrm{Ni}$, the same result was obtained.

The interfacial reaction of the eutectic $\mathrm{Sn}-3.2 \mathrm{Ag}-0.6 \mathrm{Cu}-$ $0.7 \mathrm{Ni}$ (solder D) with the Ni substrate after reflow is shown in Fig. 9(a). The addition of Ni to solder B suppressed the formation of $(\mathrm{Cu}, \mathrm{Ni})_{6} \mathrm{Sn}_{5}$, leaving the IMC layer composed of only $(\mathrm{Ni}, \mathrm{Cu})_{3} \mathrm{Sn}_{4}$. The XRD peaks of $(\mathrm{Ni}, \mathrm{Cu})_{3} \mathrm{Sn}_{4}$ appeared with the peaks of the Ni substrate in Fig. 9(b). The addition of $\mathrm{Ni}$ was effective to suppress the formation of the thick $(\mathrm{Cu}, \mathrm{Ni})_{6} \mathrm{Sn}_{5}$ IMC and, therefore, the $\mathrm{Ni}$ bearing solder can enhance the solder joint reliability in this sense.

The compositions of the IMC layer were carefully measured by EDX, nonetheless, they are subject to an uncertainty of a few atomic percent because the $(\mathrm{Ni}, \mathrm{Cu})_{3} \mathrm{Sn}_{4}$ layer was very thin. When the $\left(\mathrm{Cu}_{x} \mathrm{Ni}_{1-x}\right)_{6} \mathrm{Sn}_{5}$ IMC layer was formed, the value of $x$ was lager than 0.6 while for the case of $\left(\mathrm{N}_{y} \mathrm{Cu}_{1-y}\right)_{3} \mathrm{Sn}_{4}$ the value of $y$ was larger than 0.8 . This is similar to Table 3 and the stable composition (in mass\%) range of both IMC phases is shown in Fig. 10.

Generally, the phase formation in an as-solidified alloy and an equilibriated alloy is different even if they are of the same composition. The alloy examined in this study is somewhat between the two situations. The cooling rates of the alloys examined are $15^{\circ} \mathrm{C} / \mathrm{s}$ for the casting condition and $1^{\circ} \mathrm{C} / \mathrm{s}$ for the reflow test. In spite of a large difference in the cooling rate employed, there was no remarkable difference in phase formation observed.

It was reported that the joint reaction of $\mathrm{Sn}-\mathrm{Cu} / \mathrm{Ni}$ and $\mathrm{Sn}-$ $\mathrm{Ni} / \mathrm{Cu}$, and the heat treatment of $\mathrm{Sn}-\mathrm{Cu}-\mathrm{Ni}$ alloys result in 


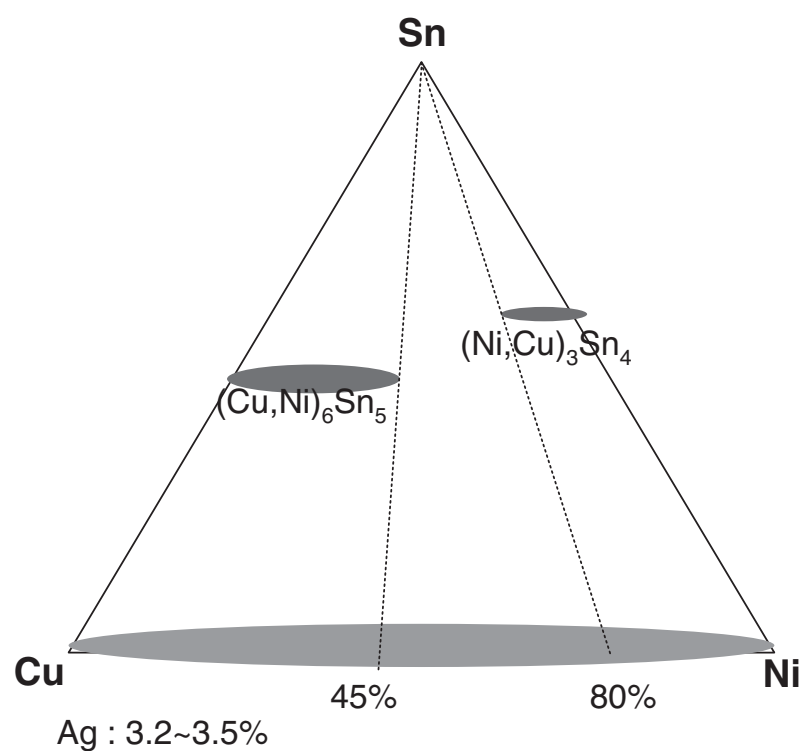

Fig. 10 Stable composition (in mass\%) ranges of $(\mathrm{Cu}, \mathrm{Ni})_{6} \mathrm{Sn}_{5}$ and $(\mathrm{Ni}, \mathrm{Cu})_{3} \mathrm{Sn}_{4}$ after reflow or casting.

formation $(\mathrm{Cu}, \mathrm{Ni})_{6} \mathrm{Sn}_{5}$ and/or $(\mathrm{Ni}, \mathrm{Cu})_{3} \mathrm{Sn}_{4}$ IMCs depending on the temperature and exact compositions, because both IMC phases have an extensive ternary solubility. ${ }^{30-34)}$ The stable composition range of IMCs in the $\mathrm{Sn}-\mathrm{Ag}-\mathrm{Cu}-\mathrm{Ni}$ quaternary solder (Fig. 10) was close to the reported $\mathrm{Sn}-\mathrm{Cu}-$ $\mathrm{Ni}$ ternary isotherm. ${ }^{32,34)}$ In the quaternary system, $\mathrm{Sn}-\mathrm{Ag}-$ $\mathrm{Cu}-\mathrm{Ni}, \mathrm{Ag}$ did not exert an effect on the solubility and stoichiometry of $\mathrm{Cu}_{6} \mathrm{Sn}_{5}$ and $\mathrm{Ni}_{3} \mathrm{Sn}_{4}$. However $(\mathrm{Cu}, \mathrm{Ni})_{3} \mathrm{Sn}$ and $\mathrm{Ni}_{3} \mathrm{Sn}_{2}$ were not observed in this study due to the relatively lower contents of $\mathrm{Cu}$ and $\mathrm{Ni}$ and shorter aging time. Based on this information it is possible to expect the type of the IMC phase as a function of $\mathrm{Cu}$ and $\mathrm{Ni}$ concentrations, after reflow and casting.

The wetting properties of the eutectic $\mathrm{Sn}-\mathrm{Ag}-\mathrm{Cu}-\mathrm{Ni}$ (solder D) were compared with the eutectic $\mathrm{Sn}-\mathrm{Ag}-\mathrm{Cu}$ (solder B) in Fig. 11. The wetting angle, $15^{\circ}$, of the $\mathrm{Ni}$ bearing solder D in Fig. 11(b) was almost the same as that of the $\mathrm{Sn}-\mathrm{Ag}-\mathrm{Cu}$ solder B. Typically the electronics industry involves multiple-pass solder operation in which solders are reflowed several times. In such operation, the wettability of the solder is extremely important. Especially, the addition of $\mathrm{Ni}$ may decrease the wetting properties but there was no significant decrease in wettability in this study, which is promising after all.

\section{Summary}

Quaternary $\mathrm{Sn}-3.24 \mathrm{Ag}-0.64 \mathrm{Cu}-0.75 \mathrm{Ni}$ eutectic composition was calculated using a Thermo-Calc program. Many advantages of $\mathrm{Ni}$ bearing solder were introduced. In the Ni bearing composite solder, there was no significant sedimentation of reinforcing particles during reflow, which took place commonly in the other composite solders. Ni addition enhanced the bonding properties and retarded the IMC growth. The wetting angle of the $\mathrm{Ni}$ bearing solder was almost the same as that of the $\mathrm{Sn}-\mathrm{Ag}-\mathrm{Cu}$.

When the ratio of excess $\mathrm{Cu} / \mathrm{Ni}$ alloyed in the original

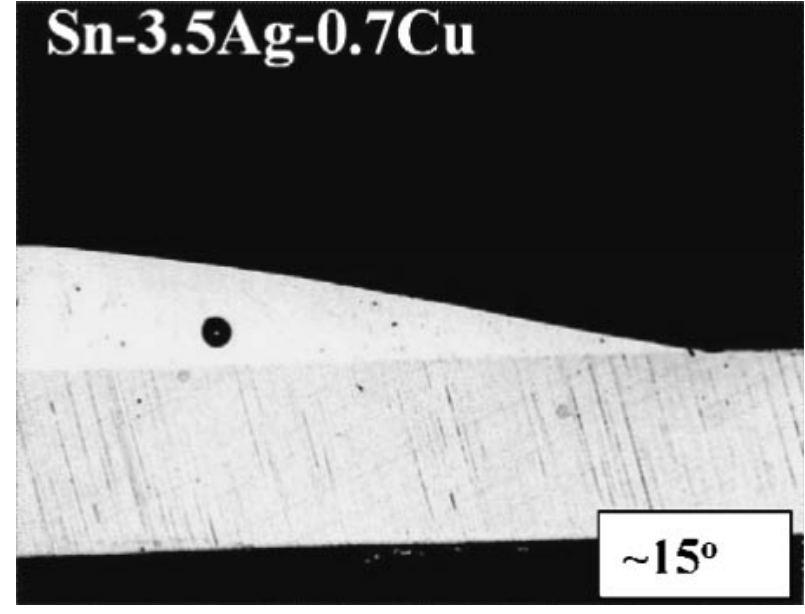

(a)

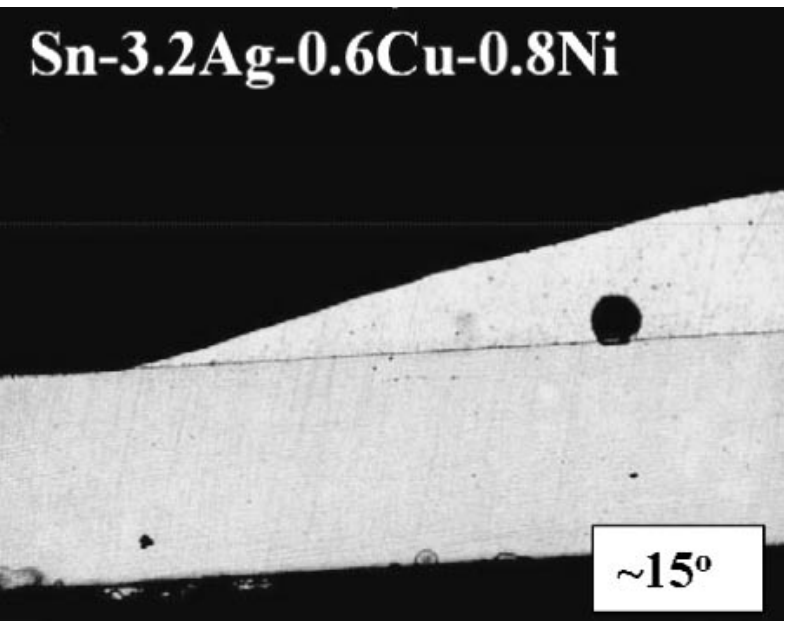

(b)

Fig. 11 Cross-sectional micrographs of (a) $\mathrm{Sn}-\mathrm{Ag}-\mathrm{Cu}$ eutectic solder, B and (b) $\mathrm{Sn}-\mathrm{Ag}-\mathrm{Cu}-\mathrm{Ni}$ eutectic solder, $\mathrm{D}$ on the $\mathrm{Cu}$ substrate after wetting test.

composite solder was $7: 3,6: 4$ and $5: 5$, the reinforcing intermetallic compound (IMC) was $\left(\mathrm{Cu}, \mathrm{Ni}_{6} \mathrm{Sn}_{5}\right.$. When the ratio was $\mathrm{Cu}: \mathrm{Ni}=3: 7$, both phases of $(\mathrm{Cu}, \mathrm{Ni})_{6} \mathrm{Sn}_{5}$ and $(\mathrm{Ni}, \mathrm{Cu})_{3} \mathrm{Sn}_{4}$ showed up while only the $(\mathrm{Ni}, \mathrm{Cu})_{3} \mathrm{Sn}_{4}$ phase was observed in the solder with a $\mathrm{Cu}: \mathrm{Ni}$ ratio of $1: 9$.

For the interfacial reaction of the eutectic $\mathrm{Sn}-3.5 \mathrm{Ag}-$ $0.7 \mathrm{Cu}$ with the rolled $\mathrm{Ni}$ substrate, the thick $(\mathrm{Cu}, \mathrm{Ni})_{6} \mathrm{Sn}_{5}$ layer was formed on the thin $(\mathrm{Ni}, \mathrm{Cu})_{3} \mathrm{Sn}_{4}$ layer. The addition of $\mathrm{Ni}$ was effective to suppress the formation of the thick $(\mathrm{Cu}, \mathrm{Ni})_{6} \mathrm{Sn}_{5} \mathrm{IMC}$. When the $\left(\mathrm{Cu}_{x} \mathrm{Ni}_{1-x}\right)_{6} \mathrm{Sn}_{5}$ IMC layer was formed, the value of $x$ was lager than 0.6 while for the case of $\left(\mathrm{N}_{y} \mathrm{Cu}_{1-y}\right)_{3} \mathrm{Sn}_{4}$ the value of $y$ was larger than 0.8 . Based on this information it is possible to expect the type of the IMC phase as a function of $\mathrm{Cu}$ and $\mathrm{Ni}$ concentration, after reflow and casting.

\section{Acknowledgments}

This work was supported by the Center for Electronic Packaging Materials (CEPM) of Korea Science and Engineering Foundation (KOSEF). 


\section{REFERENCES}

1) A. W. Gibson, S. L. Choi, K. N. Subramanian and T. R. Bieler: Proceedings of Design and Reliability of Solders and Solder Interconnects, ed. by R. K. Mahidhara, D. R. Frear, S. M. L. Sastry, K. L. Murty, P. K. Liaw and W. L. Winterbottom (TMS, Warrendale, PA, USA, 1997) pp. 97-103.

2) S. L. Choi, A. W. Gibson, J. L. McDougall, T. R. Bieler and K. N. Subramanian: Proceedings of Design and Reliability of Solders and Solder Interconnects, ed. by R. K. Mahidhara, D. R. Frear, S. M. L. Sastry, K. L. Murty, P. K. Liaw and W. L. Winterbottom, (TMS, Warrendale, PA, USA 1997) pp. 241-245.

3) K. N. Subramanian, T. R. Bieler and J. P. Lucas: J. Electron. Mater. 28 (1999) 1176-1183.

4) J. Sigelko, S. Choi, K. N. Subramanian, J. P. Lucas and T. R. Bieler: J. Electron. Mater. 28 (1999) 1184-1188.

5) S. Choi, T. R. Bieler, J. P. Lucas and K. N. Subramanian: J. Electron. Mater. 28 (1999) 1209-1215.

6) F. Guo, S. Choi, J. P. Lucas and K. N. Subramanian: J. Electron. Mater. 29 (2000) 1241-1248.

7) F. Guo, J. Lee, S. Choi, J. P. Lucas, T. R. Bieler and K. N. Subramanian: J. Electron. Mater. 30 (2001) 1073-1082.

8) F. Guo, J. Lee, J. P. Lucas, K. N. Subramanian and T. R. Bieler: J. Electron. Mater. 30 (2001) 1222-1227.

9) J. G. Lee, F. Guo, K. N. Subramanian and J. P. Lucas: Soldering and Surface Mount Tech. 14 (2002) 11-17.

10) J. G. Lee, K. C. Chen and K. N. Subramanian: J. Electron. Mater. 32 (2003) 1240-1248

11) H. Rhee and K. N. Subramanian: J. Electron. Mater. 32 (2003) 13101316.

12) J. P. Lucas, H. Rhee, F. Guo and K. N. Subramanian: J. Electron. Mater. 32 (2003) 1375-1383.

13) S. Y. Hwang, J. W. Lee and Z. H. Lee: J. Korea Foundry Soc. 22 (2002) 35-41.

14) S. Y. Hwang, J. W. Lee and Z. H. Lee: J. Electron. Mater. 31 (2002) 1304-1308.

15) B. Sundman, B. Jansson and J. O. Andersson, CALPHAD 9 (1985)
153-190.

16) F. H. Hayes, H. L. Lukas, G. Effenberg and G. Petzow: Z. Metallkd. 77 (1986) 1011-1018

17) G. Ghosh: unpublished work, Northwestern University, Evanston (1998).

18) C.-S. Oh, J.-H. Shim, B.-J. Lee and D. N. Lee: J. Alloys Compd. 238 (1996) 155-166.

19) B.-J. Lee, C.-S. Oh and J.-H. Shim: J. Electron. Mater. 25 (1996) 983989.

20) J.-H. Shim, C.-S. Oh, B.-J. Lee and D. N. Lee: Z. Metallkd. 87 (1996) 205-214.

21) G. Ghosh: Metall. Mater. Trans. 30A (1999) 1481-1482.

22) S. W. Chen and C. A. Chang: J. Electron. Mater. 33 (2004) 1071-1079.

$23)$ C. A. Chang, S. W. Chen, C. N. Chiu and Y. C. Huang: J. Electron. Mater. 34 (2005) 1135-1142.

24) J. H. Lee and D. N. Lee: J. Electron. Mater. 30 (2001) 1112-1116.

25) T. Siewert, S. Liu, D. R. Smith and J. C. Madeni: Database for Solder Properties with Emphasis on New Lead-free Solders (National Institute of Science and Technology \& Colorado School of Mines, Colorado, 2000) pp. 17-46.

26) L. Pauling: The Nature of the Chemical Bonding, Cornell University Press (1960) pp. 221-257.

27) H. Y. Chang, S. W. Chen, D. S. Wong and H. F. Hsu: J. Mater. Res. 18 (2003) 1420-1428.

28) S. V. Sattiraju, B. D. Dang, R. W. Johnson, Y. Li, J. S. Smith and M. J. Bozack: IEEE Electron. Pack. 25 (2003) 168-184.

29) J. H. Lee, D. J. Park, J. N. Heo, Y. H. Lee, D. H. Shin and Y. S. Kim: Scr. Mater. 42 (2000) 827-831.

30) W. T. Chen, C. E. Ho and C. R. Kao: J. Mater. Res. 17 (2002) 263-266.

31) D. R. Frear, J. W. Jang, J. K. Lin and C. Zhang: JOM 53 (2001) 28-32.

32) S. W. Chen, S. H. Wu and S. W. Lee: J. Electron. Mater. 32 (2003) 1188-1194.

33) J. Y. Tsai, Y. C. Hu, C. M. Tsai and C. R. Kao: J. Electron. Mater. 32 (2003) 1203-1208.

34) C. H. Lin, S. W. Chen and C. H. Wang: J. Electron. Mater. 31 (2002) 907-915. 